\title{
Differential Host Determinants Contribute to the Pathogenesis of 2009 Pandemic H1N1 and Human H5N1 Influenza A Viruses in Experimental Mouse Models
}

\author{
Anna Otte, ${ }^{*}$ Martina Sauter, ${ }^{\dagger}$ Lisa Alleva, ${ }^{\ddagger}$ \\ Sigrid Baumgarte, ${ }^{\S}$ Karin Klingel, ${ }^{\dagger}$ and \\ Gülsah Gabriel* \begin{abstract}
Experimental Virology, Hamburg, Germany; the Department for Molecular Pathology, ${ }^{\dagger}$ Institute of Pathology, University Hospital Tübingen, Tübingen, Germany; the Research School of Biology, ${ }^{\ddagger}$ The Australian National University, Canberra, Australia; and the
\end{abstract} \\ From the Heinrich-Pette-Institute, "Leibniz Institute for \\ Institute for Hygiene and Environment, ${ }^{\S}$ Hamburg, Germany
}

Influenza viruses are responsible for high morbidities in humans and may, eventually, cause pandemics. Herein, we compared the pathogenesis and host innate immune responses of a seasonal H1N1, two 2009 pandemic $H 1 N 1$, and a human $H 5 N 1$ influenza virus in experimental BALB/c and C57BL/6J mouse models. We found that both 2009 pandemic H1N1 isolates studied (A/Hamburg/05/09 and A/Hamburg/NY1580/ 09) were low pathogenic in BALB/c mice [log mouse lethal dose $50\left(M_{50}\right)>6$ plaque-forming units (PFU)] but displayed remarkable differences in virulence in C57BL/6J mice. A/Hamburg/NY1580/09 was more virulent $(\operatorname{logMLD})_{50}=3.5$ PFU) than $\mathrm{A} / \mathrm{Ham}$ burg/05/09 $\left(\operatorname{logMLD}{ }_{50}=5.2 \mathrm{PFU}\right)$ in C57BL/6J mice. In contrast, the $\mathrm{H} 5 \mathrm{~N} 1$ influenza virus was more virulent in BALB/c mice $\left.(\operatorname{logMLD})_{50}=0.3 \mathrm{PFU}\right)$ than in C57BL/6J mice $\left(\log\right.$ LLD $\left._{50}=1.8 \mathrm{PFU}\right)$. Seasonal H1N1 influenza revealed marginal pathogenicity in BALB/c or $\mathrm{C} 57 \mathrm{BL} / 6 \mathrm{~J}$ mice $\left(\log \mathrm{MLD}_{50}>6 \mathrm{PFU}\right)$. Enhanced susceptibility of $\mathrm{C} 57 \mathrm{BL} / 6 \mathrm{~J}$ mice to pandemic $\mathrm{H} 1 \mathrm{~N} 1$ correlated with a depressed cytokine response. In contrast, enhanced H5N1 virulence in BALB/c mice correlated with an elevated proinflammatory cytokine response. These findings highlight that host determinants responsible for the pathogenesis of 2009 pandemic H1N1 influenza viruses are different from those contributing to $\mathrm{H} 5 \mathrm{N1}$ pathogenesis. Our results show, for the first time to our knowledge, that the $\mathrm{C} 57 \mathrm{BL} / 6 \mathrm{~J}$ mouse strain is more appropriate for the evaluation and identifica- tion of intrinsic pathogenicity markers of 2009 pandemic H1N1 influenza viruses that are "masked" in BALB/c mice. (Am J Pathol 2011, 179:230-239; DOI: 10.1016/j.ajpath.2011.03.041)

Influenza A viruses are a continuous threat to humans because of their ability to cross species barriers and adapt to new hosts. Zoonotic H5N1 influenza viruses have repeatedly crossed species barriers and infected humans, with high fatality rates (>50\%; http://www. who.int/csr/don/2006_06_30/en, last accessed May 13, 2011). ${ }^{1,2}$ Emerging influenza viruses with an antigenically new subtype may acquire the potential to cause pandemics in the human population. ${ }^{3}$ The first pandemic of the $21^{\text {st }}$ century was announced in June 2009 by the World Health Organization in response to the emergence of a novel H1N1 influenza A virus (pH1N1). This 2009 pandemic virus derives six genes from triple-reassortant North American swine virus lineages and two genes (encoding neuraminidase and matrix protein) from Eurasian swine virus lineages. ${ }^{4,5}$ The 2009 pH1N1 influenza has resulted in $>18,000$ deaths in $>200$ countries worldwide (http://www.who.int/csr/disease/swineflu/updates/en/index. html, last accessed August 6, 2010). Most people infected with $2009 \mathrm{pH} 1 \mathrm{~N} 1$ experienced mild disease, with upper respiratory illness similar to seasonal influenza virus infection. However, gastrointestinal symptoms (including nausea, vomiting, and diarrhea) occurred more commonly in patients infected with $\mathrm{pH} 1 \mathrm{~N} 1$ than with sea-

Supported by the Sonderforschungsbereich SFB-TR19 of the German Research Association (K.K.), a grant from the European Commission FLU-PHARM (259751 to G.G.), and a grant from the Emmy-Noether program of the German Research Association (GA 1575/1-1 to G.G.).

Accepted for publication March 15, 2011.

Supplemental material for this article can be found at http://ajp. amjpathol.org or at doi: 10.1016/j.ajpath.2011.03.041.

Address reprint request to Gülsah Gabriel, Sc.D., Heinrich-Pette-Institute, Leibniz Institute for Experimental Virology, Martinistraße 52, 20251 Hamburg, Germany. E-mail: guelsah.gabriel@hpi.uni-hamburg.de. 
sonal influenza. ${ }^{6,7}$ In addition, in contrast to seasonal influenza, most of the serious illnesses caused by the 2009 pH1N1 influenza occurred among children and nonelderly adults, with approximately $90 \%$ of deaths occurring in those younger than 65 years. ${ }^{8}$ Approximately $9 \%$ to $31 \%$ of hospitalized patients were admitted to intensive care units, and $14 \%$ to $46 \%$ of these patients died. ${ }^{9-13}$

Circulating 2009 pH1N1 influenza viruses possess high sequence homologies, although variants differing from the consensus sequence have been described. ${ }^{5}$ In animal models, such as mice, ferrets, pigs, and macaques, $\mathrm{pH} 1 \mathrm{~N} 1$ isolates have caused more disease than seasonal H1N1 influenza viruses. ${ }^{14-16}$ Previously described markers predictive of host adaptation of $\mathrm{H} 5 \mathrm{~N} 1$ and 1918 pandemic influenza viruses were not present in $2009 \mathrm{pH} 1 \mathrm{~N} 1$ viruses. This suggests that unrecognized novel determinants are responsible for the sustained human-to-human transmission and the disease severity among nonelderly adults, indicating a higher pathogenic potential of this newly emerged virus. ${ }^{5}$

Small animals, such as mice, are convenient models to rapidly assess infection and the pathogenesis of newly emerged influenza viruses. BALB/C and C57BL/6J mice are commonly used inbred strains to assess influenza virus pathogenicity. BALB/c mice infected with $\mathrm{pH} 1 \mathrm{~N} 1$ influenza viruses presented increased pathogenicity compared with seasonal influenza, but lethality has not been observed and no remarkable differences in virulence among circulating $2009 \mathrm{pH} 1 \mathrm{~N} 1$ viruses have been reported for this strain. ${ }^{14,15}$

To identify the role of host genetic determinants on influenza pathogenicity, we performed a comparative analysis of the pathogenesis and host innate immune responses to seasonal H1N1, $2009 \mathrm{pH} 1 \mathrm{~N} 1$, and human H5N1 influenza viruses in experimental BALB/C and C57BL/6J mouse models. In this study, we report, for the first time to our knowledge, a marked difference in infection dynamics of 2009 pH1N1 influenza in C57BL/6J mice with severe and prolonged infection in this strain.

\section{Materials and Methods}

\section{Cells and Viruses}

Madin-Darby canine kidney cells were grown in minimal essential medium (PAA, Linz, Austria) supplemented with $10 \%$ fetal calf serum (PAA), $1 \%$ glutamine (PAA), and $1 \%$ penicillin-streptomycin (PAA). A549 (human lung carcinoma) cells were grown in Dulbecco's modified Eagle's medium (PAA) supplemented with $10 \%$ fetal calf serum (PAA), 1\% glutamine (PAA), and 1\% penicillin-streptomycin (PAA)

The $2009 \mathrm{pH} 1 \mathrm{~N} 1$ viruses A/Hamburg/05/09 (HH05) and $\mathrm{A} /$ Hamburg/NY1580/09 $(\mathrm{HH} 15)$ were isolated from pharyngeal swabs of patients before oseltamivir treatment. $\mathrm{HH} 05, \mathrm{HH} 15, \mathrm{~A} /$ Solomon Islands/3/06-like (H1N1) (seasonal H1N1), and A/Thailand/KAN-1/04 (H5N1) (human $\mathrm{H} 5 \mathrm{~N} 1$; isolated from a fatal human case ${ }^{17}$ ) were grown on Madin-Darby canine kidney cells. All virus strains were passaged only one to two times in MadinDarby canine kidney cells for virus stock generation and sequenced thereafter to exclude potential mutations upon multiple passaging. The seasonal H1N1 isolate was provided by Armin Baillot (Niedersächsisches Landesgesundheitsamt, Hannover, Germany), and the H5N1 isolate was provided by Hans-Dieter Klenk (Institute of Virology, Philipps University of Marburg, Marburg, Germany). $\mathrm{pH} 1 \mathrm{~N} 1$ clinical samples tested negative for human herpes viruses (ie, herpes simplex virus types 1 and 2 , varicella zoster virus, cytomegalovirus, and Epstein-Barr virus), human enteroviruses, influenza B virus, and human parechovirus by PCR. All experiments with the $\mathrm{pH} 1 \mathrm{~N} 1$ and $\mathrm{H} 5 \mathrm{~N} 1$ influenza viruses were performed at a biosafety level 3 facility at the HeinrichPette-Institute, Leibniz Institute of Experimental Virology, Hamburg, Germany.

\section{Clinical Information from 2009 Pandemic H1N1 Influenza Viruses Isolated from Patients}

$\mathrm{HH} 05$ ( $\mathrm{pH} 1 \mathrm{~N} 1)$ was isolated from a 22-year-old female patient who returned from Mexico in March 2009. The patient was hospitalized for 6 days and received oseltamivir treatment immediately after admission to the University Hospital Eppendorf, Hamburg. HH15 (pH1N1) was isolated from a 29-year-old male patient who was a visitor from the United States in June 2009. The patient was hospitalized for 5 days and received oseltamivir treatment immediately after admission to Asklepios Clinics, Hamburg.

Both patients presented general flulike symptoms, such as headache, cough, sore throat, myalgia, malaise, and fever (maximum temperature, $39.8^{\circ} \mathrm{C}$ ), and showed high levels of complement-reactive protein.

\section{Animal Experiments}

The animal experiments were performed according to the guidelines of the German animal protection law. All animal protocols were approved by the relevant German authorities. BALB/C and C57BL/6J mice were bred and housed at the institutional facilities under specific pathogen-free conditions or obtained from Charles River Laboratories (Sulzfeld, Germany). Mice (aged 4 to 8 weeks) were anesthetized with ketamine-xylazine (100 and 10 $\mathrm{mg} / \mathrm{kg}$, respectively) and inoculated intranasally with 50 $\mu \mathrm{L}$ of virus diluted in PBS. Mice were infected with $10^{5}$ plaque-forming units (PFU) of seasonal $\mathrm{H} 1 \mathrm{~N} 1,10^{5} \mathrm{PFU}$ of $\mathrm{HH} 05$ (pH1N1), $10^{5}$ PFU of HH15 (pH1N1), or $10^{2} \mathrm{PFU}$ of human $\mathrm{H} 5 \mathrm{~N} 1$ isolate. Control groups received PBS. Animals were observed for 14 days for weight loss and survival. On days 3 and 6 postinfection (p.i.), three animals per time point were sacrificed, organs (ie, lung, brain, and gut) were removed, and virus titers were determined by plaque assays, as previously described. ${ }^{18}$

Mouse lethal dose $50\left(M^{2} D_{50}\right)$ was assessed by infecting mice with serial 10-fold virus dilutions and calculated as previously described. ${ }^{19}$ 


\section{Automated Blood Cell Counts}

Blood samples from three infected animals per time point were collected, and automated blood cell counts on whole blood were analyzed with pocH 100iV Diff (Sysmex, Norderstedt, Germany). Frequencies of white blood cells, red blood cells, $\mathrm{Hb}$, hematocrit, platelets, Iymphocytes, and granulocytes were measured. Recommended settings and calibrations for mouse strain-specific hematology were set according to the manufacturer's protocol.

\section{IHC Stainings}

The lungs and guts of three infected animals at 6 days p.i. were processed for immunohistochemistry (IHC). For $\mathrm{IHC}$ stainings, deparaffinized tissues were pretreated with 0.1 $\mathrm{mol} / \mathrm{L}$ citrate buffer ( $\mathrm{pH} \mathrm{6.0)}$ and incubated with a polyclonal ferret antibody raised against $\mathrm{A} / \mathrm{Vic} / 3 / 75$ influenza virus (H3N2) (1:500; provided by the World Health Organization). The primary antibody cross-reacts with the nucleoprotein of several influenza virus subtypes, as previously described.20,21 As a secondary antibody, a biotinylated anti-ferret antibody (1:200; Rockland, Gilbertsville, PA) was used, followed by the application of the Zytochem-Plus HRP kit and AEC as substrate (Zytomed, Berlin, Germany) under the conditions described by the manufacturer. Controls using normal rat serum were run to exclude nonspecific staining. Tissues were counterstained with hematoxylin, as previously described. ${ }^{18}$

\section{Cytokine Assays}

Cytokine levels were measured from pooled samples (three animals for lung homogenates and four to seven animals for serum specimens) by enzyme-linked immunosorbent assay for macrophage chemoattractant protein (MCP)-1, tumor necrosis factor (TNF)- $\alpha$, interferon (IFN)- $\gamma$, IL-4, IL-6, and IL-10 using the mouse Quantikine assay (R\&D Systems, Minneapolis, MN) or the mouse Legend Max (BioLegend, San Diego, CA), according to the manufacturer's instructions. The mean titers of two to four experiments are presented. Cytokine detection limits were as follows: $2 \mathrm{pg} / \mathrm{mL}$ for MCP-1, $1.5 \mathrm{pg} / \mathrm{mL}$ for TNF- $\alpha$, $8 \mathrm{pg} / \mathrm{mL}$ for IFN- $\gamma, 0.5 \mathrm{pg} / \mathrm{mL}$ for IL-4, 1.6 or $2 \mathrm{pg} / \mathrm{mL}$ for $\mathrm{IL}-6$, and 4 or $28.8 \mathrm{pg} / \mathrm{mL}$ for IL-10.

\section{Sequencing of HHO5 and HH15}

The gene segments of the $2009 \mathrm{pH} 1 \mathrm{~N} 1$ isolates (ie, $\mathrm{HH} 05$ and $\mathrm{HH} 15$ ) were sequenced as previously described ${ }^{22}$ and deposited in GenBank as follows: HH05, accession no. HQ111361 (PB2), HQ111362 (PB1), HQ111363 (PA), HQ111365 (NP), HQ111364 (HA), HQ111366 (NA), HQ111367 (M), and HQ111368 (NS); and HH15, accession no. GU480807 (PB2), HQ104924 (PB1), HQ104925 (PA), HM598305 (NP), HQ104926 (HA), HQ104927 (NA), HQ104928 (M), and HQ104929 (NS).

\section{Growth Curves}

A549 cells were infected with seasonal $\mathrm{H} 1 \mathrm{N1}, \mathrm{HH} 05$, and $\mathrm{HH} 15$ ( $\mathrm{pH} 1 \mathrm{~N} 1)$ at a multiplicity of infection of 0.01 and human $\mathrm{H} 5 \mathrm{~N} 1$ at a multiplicity of infection of 0.001 . At 24, 48, 72, and 96 hours p.i., supernatants were collected and plaque titers were determined on Madin-Darby canine kidney cells. ${ }^{18}$ The growth curves shown are the average result of two independent experiments.

\section{Results}

Pathogenicity of Seasonal H1N1, 2009

Pandemic H1N1, and Human H5N1 Influenza A Viruses in BALB/C and C57BL/6J Mice

$\mathrm{BALB} / \mathrm{c}$ mice infected with seasonal $\mathrm{H} 1 \mathrm{~N} 1$ influenza virus had marginal weight loss, and all animals survived (Figure 1, A and B). Infection with $\mathrm{HH} 05$ and $\mathrm{HH} 15$ led to $10 \%$ to $15 \%$ weight loss, and $93 \%$ survived (Figure 1, A and $B$ ). In contrast, all animals infected with human $\mathrm{H} 5 \mathrm{~N} 1$ influenza succumbed to infection, with severe weight loss (Figure 1, A and B).

Similar to the BALB/C model, all C57BL/6J mice infected with seasonal H1N1 influenza survived, with no significant weight loss (Figure 1, C and D). In contrast to $\mathrm{BALB} / \mathrm{c}$, infection of $\mathrm{C} 57 \mathrm{BL} / 6 \mathrm{~J}$ mice with $\mathrm{HH} 05$ and $\mathrm{HH} 15$ displayed remarkable differences in pathogenicity. HH05-infected animals experienced 66\% survival, whereas $\mathrm{HH} 15$ infection was $100 \%$ lethal (Figure 1C). $\mathrm{HH} 15$-infected animals lost more weight than $\mathrm{HH} 05$-infected mice (Figure 1D). All H5N1-infected animals succumbed to infection, with severe weight loss (Figure 1, C and D).

To assess the virulence of the influenza strains in both experimental mouse models, we determined the $\mathrm{MLD}_{50}$ in BALB/C and C57BL/6J mice (Table 1). Seasonal H1N1 is not lethal in BALB/C (logMLD $\left.{ }_{50}>6 \mathrm{PFU}\right)$ and C57BL/6J (logMLD $\left._{50}>6 \mathrm{PFU}\right)$ mice. $\mathrm{HH} 15$ is low pathogenic in $\mathrm{BALB} / \mathrm{c}$ mice $\left(\operatorname{logMLD}_{50}>6 \mathrm{PFU}\right)$ but highly virulent in C57BL/6J mice $\left(\operatorname{logMLD}{ }_{50}=3.5 \mathrm{PFU}\right)$. $\mathrm{HH} 15$ is more virulent than $\mathrm{HHO5}\left(\operatorname{logMLD} \mathrm{D}_{50}=5.2 \mathrm{PFU}\right)$ in C57BL/6J mice. Both $\mathrm{HHO5}$ and $\mathrm{HH} 15$ are low pathogenic in $\mathrm{BALB} / \mathrm{c}$ mice $\left(\operatorname{logMLD}_{50}>6 \mathrm{PFU}\right)$. H5N1 influenza is even more virulent for BALB/c mice $\left(\log M_{L} D_{50}=0.3\right.$ $\mathrm{PFU})$ than $\mathrm{C} 57 \mathrm{BL} / 6 \mathrm{~J}$ mice $\left(\operatorname{logMLD}_{50}=1.8 \mathrm{PFU}\right)$. Thus, increased virulence of $\mathrm{H} 5 \mathrm{~N} 1$ influenza virus for BALB/C mice becomes visible, in contrast to Figure $1 \mathrm{~A}$, where the infection dose used was six times higher in terms of $\mathrm{MLD}_{50}$ for BALB/c than C57BL/6J mice.

In summary, seasonal H1N1 influenza is not lethal for both $\mathrm{BALB} / \mathrm{c}$ and $\mathrm{C} 57 \mathrm{BL} / 6 \mathrm{~J}$ mice. H5N1 influenza is more pathogenic for BALB/c than C57BL/6J mice. In contrast, C57BL/6J animals are more susceptible to $2009 \mathrm{pH} 1 \mathrm{~N} 1$ influenza viruses displaying differential pathogenicities, which is not observed in BALB/c mice. Our data further suggest that host determinants contributing to 2009 $\mathrm{pH} 1 \mathrm{~N} 1$ pathogenesis are different from those responsible for H5N1 pathogenesis. 
A

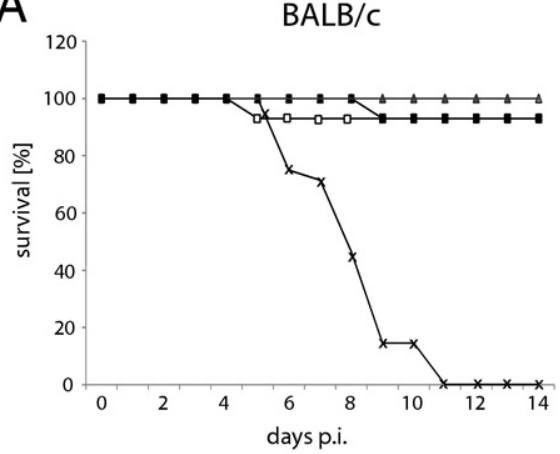

C

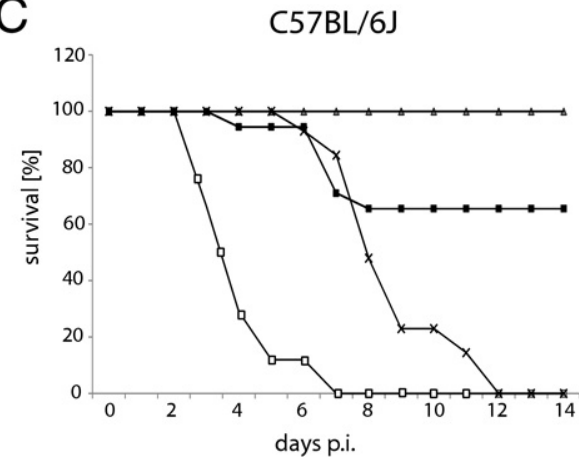

B
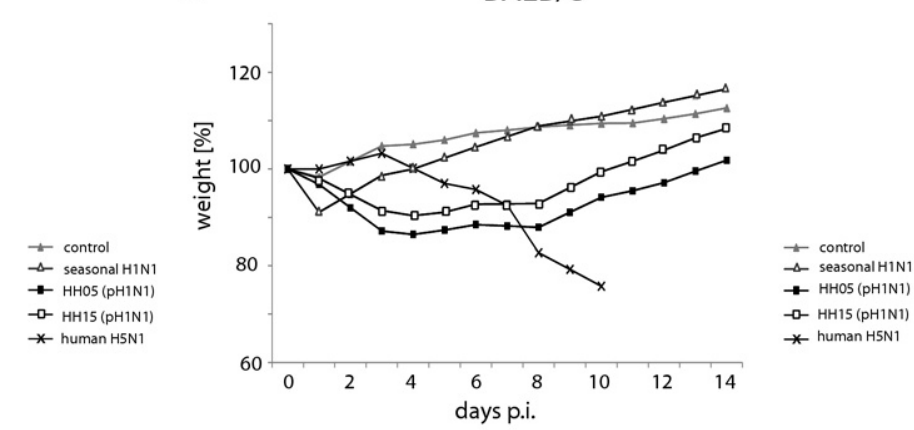

D

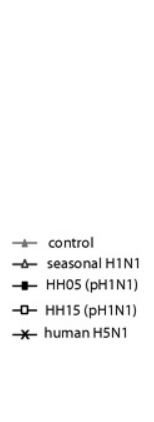

$B A L B / C$

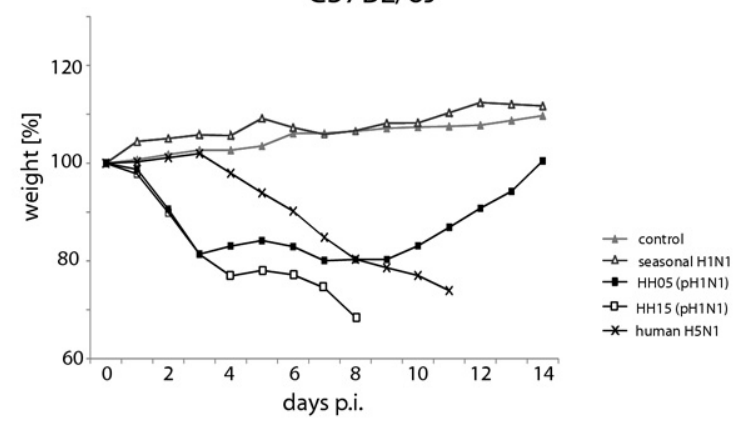

Figure 1. Pathogenicity in BALB/c and C57BL/6J mice. BALB/c (A and $\mathbf{B})$ or C57BL/6J $(\mathbf{C}$ and $\mathbf{D})$ mice were infected with $10^{5} \mathrm{PFU}$ of seasonal H1N1 $(n=14)$, HH05 (pH1N1) $(n=21)$, and HH15 (pH1N1) $(n=21)$ and with $10^{2}$ PFU of human H5N1 $(n=20)$ and observed for survival and weight loss for 14 days. Survival and weight loss are presented for infected BALB/c (A and $\mathbf{B}$, respectively) and C57BL/6J (C) and $\mathbf{D}$, respectively) mice. Control groups received PBS.

\section{Elevated Virus Lung Titers Correlate with Enhanced Virulence in BALB/c but Not in C57BL/6J Mice}

We then analyzed organ titers of seasonal H1N1, HH05, and $\mathrm{HH} 15$ and human $\mathrm{H} 5 \mathrm{~N} 1$ influenza virus-infected BALB/C and C57BL/6J mice (Figure 2, A and B).

At 3 days p.i., no significant differences in lung titers among seasonal $\mathrm{H} 1 \mathrm{~N} 1, \mathrm{HH} 05, \mathrm{HH} 15$, or $\mathrm{H} 5 \mathrm{~N} 1$ influenza virus-infected BALB/c mice were observed (Figure 2A). At 6 days p.i., lung titers were lowest in BALB/C mice infected with seasonal $\mathrm{H} 1 \mathrm{~N} 1$, followed by $\mathrm{HH} 05$ influenza. The highest lung titers were detected in animals infected with $\mathrm{HH} 15$ and $\mathrm{H} 5 \mathrm{~N} 1$. While infection with seasonal $\mathrm{H} 1 \mathrm{~N} 1$, $\mathrm{HH} 05$, and $\mathrm{HH} 15$ was mainly restricted to the lung, $\mathrm{H} 5 \mathrm{~N} 1$ infection spread to extrapulmonary organs, such as the brain and gut of BALB/c mice (Figure $2 \mathrm{~A}$ ).

In C57BL/6J mice, on days 3 and 6 p.i., no significant differences in the overall lung titers were observed in

Table 1. $\mathrm{MLD}_{50}$ in $\mathrm{BALB} / \mathrm{C}$ and $\mathrm{C} 57 \mathrm{BL} / 6 \mathrm{~J}$ Mice

\begin{tabular}{ccccc}
\hline & \multicolumn{4}{c}{ MLD $_{50}$ (log PFU) } \\
\cline { 2 - 5 } Mice & $\begin{array}{c}\text { Seasonal } \\
\text { H1N1 }\end{array}$ & $\begin{array}{c}\text { HH05 } \\
(\mathrm{pH} 1 \mathrm{N1})\end{array}$ & $\begin{array}{c}\mathrm{HH} 15 \\
(\mathrm{pH} 1 \mathrm{~N} 1)\end{array}$ & $\begin{array}{c}\text { Human } \\
\text { H5N1 }\end{array}$ \\
\hline BALB/C & $>6$ & $>6$ & $>6$ & 0.3 \\
C57BL/6J & $>6$ & 5.2 & 3.5 & 1.8 \\
\hline
\end{tabular}

$\mathrm{BALB} / \mathrm{C}$ and $\mathrm{C} 57 \mathrm{BL} / 6 \mathrm{~J}$ mice were infected with serial 10-fold virus dilutions ( $10^{6}$ to $10^{\circ} \mathrm{PFU}$ ) of seasonal $\mathrm{H} 1 \mathrm{~N} 1, \mathrm{HH} 05$ (pH1N1), and $\mathrm{HH} 15$ ( $\mathrm{pH} 1 \mathrm{N1}$ ) and human H5N1 and observed for 14 days p.i. The MLD 50 was calculated as described by Reed and Muench. ${ }^{19}$ seasonal H1N1-, HH05-, HH15-, and H5N1-infected mice (Figure 2B). However, significantly high virus titers were detected in the gut of $\mathrm{HH} 15$-infected mice on day 6 p.i., but not in seasonal $\mathrm{H} 1 \mathrm{~N} 1$ - or $\mathrm{HH} 05$-infected animals (Figure 2B).

Taken together, levels of virus lung titers correlate with the grade of virulence in infected BALB/c mice, suggesting that virus lung titers are an important marker to predict lethality of a virus strain in this host. In contrast, virus lung titers do not correlate with enhanced lethal outcome in C57BL/6J mice. This suggests that, in C57BL/6J mice, additional host factors contribute to lethal outcome.

\section{Similar Lung Pathological Features and Virus Tropism in BALB/C and C57BL/6J Mice}

BALB/C mice (Figure 3, A-E) infected with seasonal H1N1 influenza (Figure 3B) presented only few local mononuclear infiltrations and single virus-infected cells compared with uninfected controls (Figure 3A). HH05infected BALB/c mice (Figure $3 \mathrm{C}$ ) revealed comparably more infected alveolar epithelial cells in association with inflammatory cells than those infected with seasonal H1N1. More virus-positive alveolar epithelial cells, relatively more plasma cells and macrophages, and extended capillaries were found in $\mathrm{HH} 15$-infected mice (Figure 3D) compared with HH05-infected animals. The H5N1-infected animals (Figure 3E) presented the most virus-positive alveolar and bronchial epithelial cells, with 


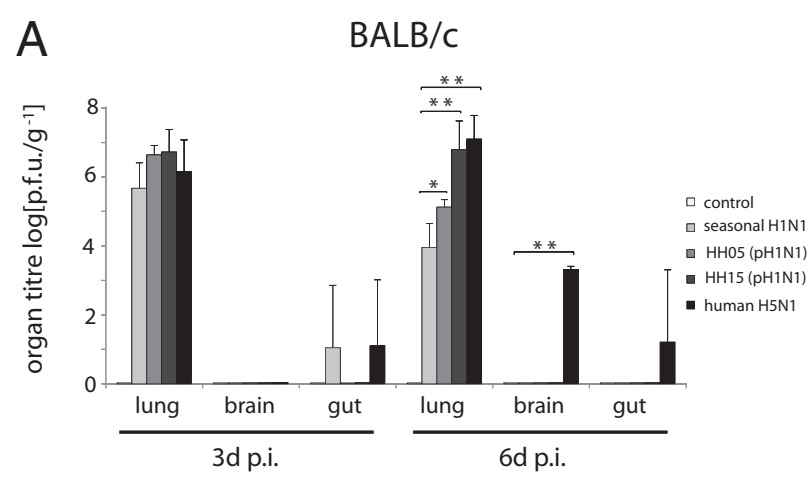

B C57BL/6J

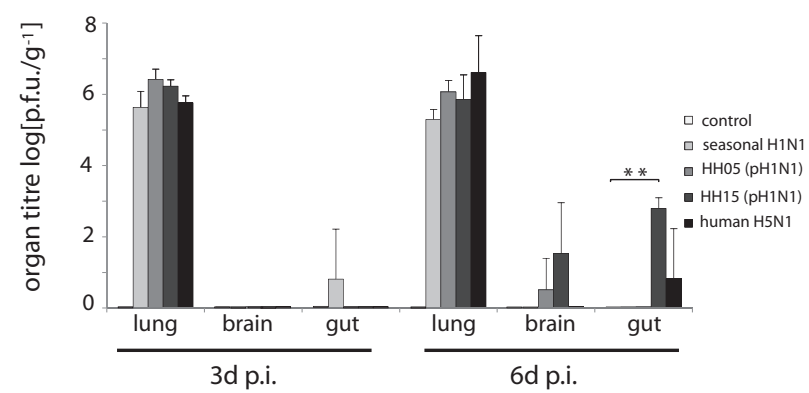

Figure 2. Organ tropism in $\mathrm{BALB} / \mathrm{c}$ and $\mathrm{C} 57 \mathrm{BL} / 6 \mathrm{~J}$ mice. $\mathrm{BALB} / \mathrm{c}(\mathbf{A})$ or C57BL/6J (B) mice were infected with $10^{5}$ PFU of seasonal H1N1, HH05, and HH15 (pH1N1) and with $10^{2}$ PFU of human H5N1. Virus titers in lung, brain, and gut homogenates of three animals per time point were determined by plaque assays on day 3 or 6 p.i. No virus was detected in uninfected control groups. The statistical significance of differences in virus titers was calculated by the Student's $t$-test $\left({ }^{*} P<0.05\right.$ and $\left.{ }^{* *} P<0.01\right)$.

pathological features comparable to $\mathrm{HH} 15$-infected mice revealing diffuse hemorrhages.

C57BL/6J mice (Figure 3, F-J) infected with seasonal H1N1 (Figure 3G) presented focal areas with mononuclear infiltrates compared with uninfected controls (Figure 3F) and single virus-positive alveolar and bronchial epithelial cells. HHO5-infected animals presented more infected alveolar epithelial cells and mononuclear inflammatory areas with extended capillaries (Figure $3 \mathrm{H}$ ) compared with animals infected with seasonal H1N1. Lung pathological features were more severe in $\mathrm{HH} 15$ - than in $\mathrm{HHO5}$-infected mice, with numerous virus-positive bronchial and alveolar epithelial cells and inflamed and destroyed alveolar structures (Figure 3l). Severe diffuse alveolar destruction and hemorrhages with numerous infected alveolar epithelial cells were observed in H5N1-infected mice (Figure 3J).

In summary, no differences in lung pathological features and virus tropism are observed with the respective virus strain in both mouse models. Seasonal H1N1 leads to marginal inflammation, followed by $\mathrm{HHO5}$ infection. $\mathrm{HH} 15$ and $\mathrm{H} 5 \mathrm{~N} 1$ viruses cause severe pneumonia in both mouse models. These findings further suggest that, in addition to the virus ability to replicate in the lung, other host factors contribute to the differential pathogenicity in $\mathrm{BALB} / \mathrm{C}$ and $\mathrm{C} 57 \mathrm{BL} / 6 \mathrm{~J}$ mice.

\section{Enhanced Viral Pathogenicity Correlates with Lymphopenia in the Respective Mouse Model}

Blood cell parameters were compared for infection of BALB/C and C57BL/6J mice (Table 2 and Table 3, respectively).

In BALB/c mice (Table 2) infected with seasonal H1N1, $\mathrm{HH} 05$, and $\mathrm{HH} 15$, white blood cells slightly decreased at 3 days p.i. but increased again at 6 days p.i., comparable to uninfected controls. White blood cell counts were significantly reduced in $\mathrm{H} 5 \mathrm{~N} 1$-infected animals at 6 days p.i. $(P<0.01)$ but not in $\mathrm{HH} 05$ - or $\mathrm{HH} 15$-infected animals compared with seasonal H1N1-infected groups. Hb levels were significantly reduced in $\mathrm{H} 5 \mathrm{~N} 1$-infected mice at 3 days p.i. $(P<0.02)$. Furthermore, in H5N1-infected animals, hematocrit levels were significantly elevated at 3 days p.i. $(P<0.02)$ and 6 days p.i. $(P<0.01)$. Severe lymphopenia, with a decrease of $>80 \%$ in lymphocyte counts, was observed in BALB/c mice infected with human H5N1 influenza at 6 days p.i. $(P<0.002)$. No significant differences were detected in other parameters assessed in BALB/c mice.

In C57BL/6J mice (Table 3) infected with $\mathrm{HHO5}$ and $\mathrm{HH} 15$, white blood cell counts significantly decreased at 3 days p.i. ( $P<0.01$ and $P<0.006$, respectively) compared with seasonal $\mathrm{H} 1 \mathrm{~N} 1$ influenza-infected animals. In $\mathrm{HH} 05$-infected animals, white blood cells increased again at 6 days p.i., similar to seasonal H1N1-infected mice and uninfected controls. In contrast, $\mathrm{HH} 15$-infected mice presented prolonged reduced white blood cells at 6 days p.i. $(P<0.005)$, similar to H5N1-infected animals $(P<0.009)$. Accordingly, $\mathrm{HH} 05-$ and $\mathrm{HH} 15$-infected mice presented significantly reduced lymphocytes at 3 days p.i. ( $P<0.009$ and $P<0.002$, respectively) compared with seasonal H1N1-infected animals. In $\mathrm{HH} 05-$ infected animals, lymphocyte levels increased again at 6 days p.i., similar to seasonal $\mathrm{H} 1 \mathrm{~N} 1$-infected groups and uninfected controls. HH15-infected mice presented severe lymphopenia, with a decrease in lymphocyte counts by $>50 \%$, comparable to H5N1-infected animals at 6 days p.i. ( $P<0.002$ and $P<0.002$, respectively).

Taken together, these observations show that $\mathrm{HH} 15$ infection leads to prolonged lymphopenia in C57BL/6J mice, in contrast to $\mathrm{HH} 05$. H5N1 leads to severe lymphopenia in BALB/c mice and, to a lesser extent, in C57BL/6J mice. Thus, grade of lymphopenia correlates with lethal outcome in the given host.

\section{Enhanced pH1N1 Pathogenicity Correlates with a Depressed Cytokine Response, whereas Increased H5N1 Pathogenicity Correlates with an Elevated Proinflammatory Cytokine Response}

It was described before that BALB/c mice were genetically prone to mount a predominantly type 2 helper T-cell (Th2) response, whereas C57BL/6J mice generate a predominantly Th1 response. ${ }^{23}$ Therefore, we determined local (Figure 4, A and B) and systemic (Figure 4, C and D) 


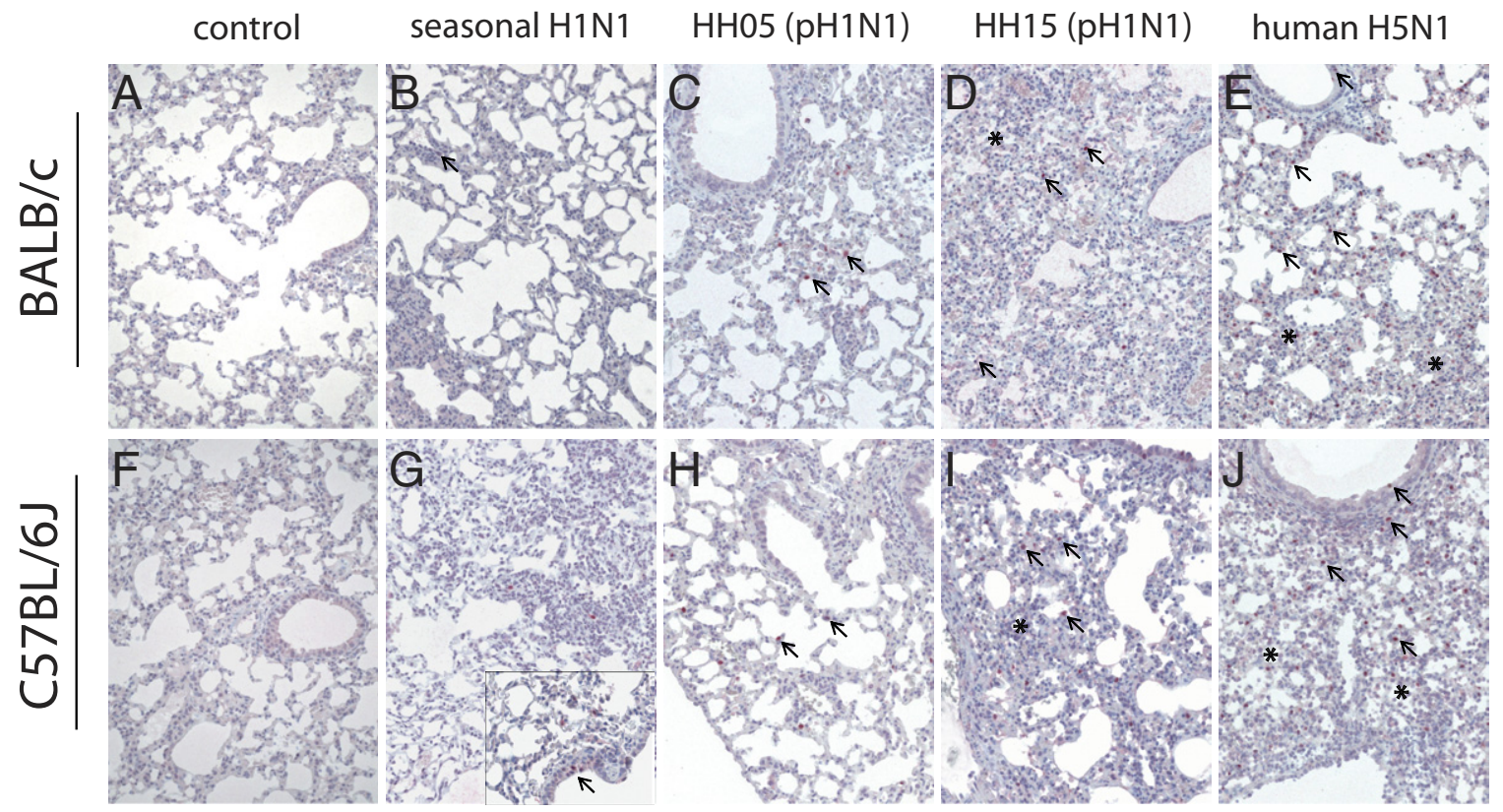

Figure 3. Lung pathological features in BALB/c and C57BL/6J mice. Mice were infected with $10^{5}$ PFU of seasonal H1N1 (B and G), HH05 (C and H), and HH15 (D and $\mathbf{I}$ ) (pH1N1) and with $10^{2}$ PFU of human H5N1 (E and $\mathbf{J}$ ). Control groups received PBS (A and $\mathbf{F}$ ). IHC stainings were performed from the lungs of three infected $\mathrm{BALB} / \mathrm{c}$ (top) and C57BL/6J (bottom) mice obtained on day 6 p.i. using a polyclonal antibody, as previously described. ${ }^{18,21}$ Counterstaining with hematoxylin was performed as previously described. ${ }^{18}$ Antigen-positive cells are red-brown. Arrows indicate some infected cells; and asterisks, largely destructed and infiltrated areas Original magnification, $\times 400$ (all images were obtained using a light microscope).

levels of Th1 cytokines (ie, TNF- $\alpha$, IFN- $\gamma$, and MCP-1) and Th2 cytokines (ie, IL-4, IL-6, and IL-10) ${ }^{23,24}$ in infected $\mathrm{BALB} / \mathrm{C}$ and C57BL/6J mice (Figure 4).

Local cytokine levels in the lung revealed that BALB/C mice were generally able to mount cytokine responses of greater magnitude than $\mathrm{C} 57 \mathrm{BL} / 6 \mathrm{~J}$ mice upon infection with $\mathrm{HH} 05, \mathrm{HH} 15$, or human $\mathrm{H} 5 \mathrm{~N} 1$ influenza viruses. No significant differences in the host innate immune response were observed in seasonal H1N1-infected BALB/c and C57BL/6J mice, with the exception of IFN- $\gamma$, which was significantly increased in BALB/c mice (Figure 4A). Levels of TNF- $\alpha$, IFN- $\gamma$, and especially IL-10 were highly elevated in $\mathrm{HHO5}$ - and $\mathrm{HH} 15$-infected BALB/C mice, in contrast to C57BL/6J mice. IL-4 levels were significantly increased in HHO5-infected BALB/C compared with C57BL/6J mice. Interestingly, HH05 infection led to significantly higher induction of IL-10 compared with $\mathrm{HH} 15$ infection in BALB/c, but not in C57BL/6J, mice. In contrast to $\mathrm{pH} 1 \mathrm{~N} 1$ infections, no alterations in IL-4 and IL-10 levels were observed in H5N1-infected BALB/C or C57BL/6J mice (Figure 4B). Furthermore, in contrast to pH1N1 infections, H5N1-infected animals presented highly elevated proinflammatory cytokine levels of TNF- $\alpha$, IFN- $\gamma$, MCP-1, and IL-6 in BALB/C mice and, to a lesser extent, in C57BL/6J mice. Systemic cytokine levels detected in the serum specimens of infected animals were generally lower compared with cytokine responses in the lungs (Figure 4, C and D). With the exception of IL-4, cytokine levels were either not detectable or slightly higher than detection limits in seasonal H1N1-infected $\mathrm{BALB} / \mathrm{c}$ and $\mathrm{C} 57 \mathrm{BL} / 6 \mathrm{~J}$ mice. A significantly elevated cytokine response was only detected for IFN- $\gamma$ in $\mathrm{HHO}$ and $\mathrm{HH} 15$-infected BALB/c mice, consistent with local lung response. Highest levels were detected for IFN- $\gamma$

Table 2. Blood Cell Count in BALB/c Mice Infected with $10^{5}$ PFU of Seasonal H1N1, HH05 (pH1N1), and HH15 (pH1N1) and with 10² PFU of Human H5N1

\begin{tabular}{|c|c|c|c|c|c|c|c|c|c|}
\hline \multirow{2}{*}{$\begin{array}{c}\text { Type of blood } \\
\text { cell }\end{array}$} & \multirow[b]{2}{*}{ Controls } & \multicolumn{2}{|c|}{ Seasonal H1N1 } & \multicolumn{2}{|c|}{$\mathrm{HH} 05$ (pH1N1) } & \multicolumn{2}{|c|}{$\mathrm{HH} 15$ (pH1N1) } & \multicolumn{2}{|c|}{ Human H5N1 } \\
\hline & & 3 days p.i. & 6 days p.i. & 3 days p.i. & 6 days p.i. & 3 days p.i. & 6 days p.i. & 3 days p.i. & 6 days p.i. \\
\hline WBCs $\left(10^{3} / \mathrm{mm}^{3}\right)$ & $7.3 \pm 1.8$ & $5.3 \pm 1.1$ & $7.3 \pm 1.3$ & $5.0 \pm 1.4$ & $7.4 \pm 1.3$ & $4.8 \pm 0.4$ & $7.8 \pm 0.7$ & $6.7 \pm 1.0$ & $2.5 \pm 0.6^{\star}$ \\
\hline $\operatorname{RBCs}\left(10^{3} / \mathrm{mm}^{3}\right)$ & $10.7 \pm 0.7$ & $9.4 \pm 0.4$ & $9.9 \pm 0.1$ & $10.4 \pm 1.6$ & $11.3 \pm 0.8$ & $10.8 \pm 0.6$ & $11.1 \pm 0.3$ & $11.4 \pm 0.4$ & $11.5 \pm 0.7$ \\
\hline $\mathrm{Hb}(\mathrm{g} / \mathrm{dL})$ & $19.0 \pm 1.2$ & $17.3 \pm 1.0$ & $17.4 \pm 0.4$ & $18.7 \pm 2.4$ & $19.9 \pm 1.2$ & $19.2 \pm 1.0$ & $19.8 \pm 0.3$ & $20.0 \pm 0.7^{*}$ & $20.0 \pm 1.6$ \\
\hline $\mathrm{HCT}(\%)$ & $49.6 \pm 1.7$ & $46.4 \pm 3.0$ & $49.8 \pm 0.3$ & $48.0 \pm 7.2$ & $52.1 \pm 3.9$ & $49.7 \pm 3.7$ & $50.8 \pm 1.6$ & $52.9 \pm 0.3^{*}$ & $54.8 \pm 2.1^{\star}$ \\
\hline PLTs $\left(10^{3} / \mathrm{mm}^{3}\right)$ & $823 \pm 227$ & $1007 \pm 218$ & $967 \pm 101$ & $620 \pm 410$ & $778 \pm 484$ & $591 \pm 180$ & $598 \pm 251$ & $870 \pm 308$ & $1005 \pm 25$ \\
\hline LYMs $\left(10^{3} / \mathrm{mm}^{3}\right)$ & $5.4 \pm 1.1$ & $3.6 \pm 0.7$ & $4.8 \pm 1.0$ & $3.5 \pm 1.2$ & $4.1 \pm 1.2$ & $3.2 \pm 0.4$ & $4.3 \pm 0.8$ & $4.0 \pm 0.3$ & $0.7 \pm 0.0^{*}$ \\
\hline GRAs $\left(10^{3} / \mathrm{mm}^{3}\right)$ & $1.9 \pm 0.9$ & $1.7 \pm 0.5$ & $2.5 \pm 0.4$ & $1.5 \pm 0.3$ & $3.3 \pm 0.2$ & $1.6 \pm 0.0$ & $3.5 \pm 0.6$ & $2.7 \pm 0.7$ & $1.8 \pm 0.6$ \\
\hline
\end{tabular}

Data are given as the mean \pm SD frequency using individual analysis. Blood samples were taken from three animals per time point, and automated blood cell counts were performed. Statistical analysis was performed with the Student's t-test.

${ }^{*}$ Asterisk indicates significance.

GRA, granulocyte; HCT, hematocrit; LYM, lymphocyte; PLT, platelet; RBC, red blood cell; WBC, white blood cell. 
Table 3. Blood Cell Count in C57BL/6J Mice Infected with $10^{5}$ PFU of Seasonal H1N1, HH05 (pH1N1), and HH15 (pH1N1) and with 10² PFU of Human H5N1

\begin{tabular}{|c|c|c|c|c|c|c|c|c|c|}
\hline \multirow{2}{*}{$\begin{array}{l}\text { Type of blood } \\
\text { cell }\end{array}$} & \multirow[b]{2}{*}{ Controls } & \multicolumn{2}{|c|}{ Seasonal H1N1 } & \multicolumn{2}{|c|}{ HH05 (pH1N1) } & \multicolumn{2}{|c|}{$\mathrm{HH} 15$ (pH1N1) } & \multicolumn{2}{|c|}{ Human H5N1 } \\
\hline & & 3 days p.i. & 6 days p.i. & 3 days p.i. & 6 days p.i. & 3 days p.i. & 6 days p.i. & 3 days p.i. & 6 days p.i. \\
\hline WBCs $\left(10^{3} / \mathrm{mm}^{3}\right)$ & $9.4 \pm 2.8$ & $10.3 \pm 1.2$ & $9.8 \pm 1.0$ & $5.5 \pm 1.4^{*}$ & $10.2 \pm 0.5$ & $5.9 \pm 0.8^{*}$ & $5.8 \pm 0.8^{*}$ & $10.3 \pm 0.5$ & $5.8 \pm 1.1^{*}$ \\
\hline $\operatorname{RBCs}\left(10^{3} / \mathrm{mm}^{3}\right)$ & 1.3 & $10.9 \pm 0.3$ & $9.3 \pm 6.0$ & $11.3 \pm 0.8$ & $9.9 \pm 0.7$ & $11.7 \pm 1.0$ & $11 . .3 \pm 0.6$ & $10.4 \pm 0.1$ & $10.4 \pm 0.4$ \\
\hline$y / d L)$ & $15.1 \pm 2.0$ & $16.8 \pm 0.4$ & $14.6 \pm 0.7$ & $17.7 \pm 1.4$ & $15.4 \pm 0.8$ & $18.5 \pm 1.3$ & $16.9 \pm 0.6$ & $16.2 \pm 0.1$ & $16.6 \pm 0.6$ \\
\hline $\mathrm{HCT}(\%)$ & $48.1 \pm 6.9$ & $47.6 \pm 1.5$ & $40.7 \pm 2.0$ & $48.6 \pm 3.9$ & $41.7 \pm 2.9$ & $50.9 \pm 4.1$ & $47.9 \pm 2.0$ & $45.3 \pm 0.2$ & $45.2 \pm 1.3$ \\
\hline $\operatorname{PLTs}\left(10^{3} / \mathrm{mm}^{3}\right)$ & $1051 \pm 303$ & $779 \pm 260$ & $1248 \pm 76$ & $1541 \pm 172$ & $1417 \pm 289$ & $1479 \pm 85$ & $1334 \pm 223$ & $1137 \pm 105$ & $1332 \pm 262$ \\
\hline LYMs $\left(10^{3} / \mathrm{mm}^{3}\right)$ & $7.9 \pm 2.3$ & $8.2 \pm 1.0$ & $8.0 \pm 0.8$ & $3.8 \pm 1.3^{*}$ & $6.1 \pm 0.8$ & $3.7 \pm 0.7^{*}$ & $3.5 \pm 0.7^{*}$ & $7.9 \pm 1.1$ & $3.6 \pm 0.7^{*}$ \\
\hline GRAs $\left(10^{3} / \mathrm{mm}^{3}\right)$ & $1.6 \pm 0.6$ & $2.1 \pm 0.4$ & $1.8 \pm 0.2$ & $1.6 \pm 0.2$ & $4.1 \pm 0.8$ & $2.2 \pm 0.3$ & $2.3 \pm 0.6$ & $2.3 \pm 0.9$ & $2.2 \pm 0.4$ \\
\hline
\end{tabular}

Data are given as the mean \pm SD frequency using individual analysis. Blood samples were obtained from three animals per time point, and automated blood cell counts were performed. Statistical analysis was performed with the Student's $t$-test.

${ }^{*}$ Asterisk indicates significance.

GRA, granulocyte; HCT, hematocrit; LYM, lymphocyte; PLT, platelet; RBC, red blood cell; WBC, white blood cell.

and IL-10 in H5N1-infected BALB/C mice and for MCP-1 in C57BL/6J mice (Figure 4, C and D).

Taken together, increased susceptibility observed in pH1N1-infected C57BL/6J mice correlates with significantly lowered production of Th1 and Th2 cytokines. In contrast, increased H5N1 pathogenicity in BALB/c mice correlates with elevated levels of proinflammatory cytokines, such as TNF- $\alpha$, IFN- $\gamma$, MCP-1, and IL-6. These findings suggest that an inappropriate or absent cytokine response might significantly contribute to increased susceptibility of C57BL/6J mice to pH1N1 influenza.

\section{Discussion}

Herein, we analyzed the pathogenesis, virus replication, virus tropism, and innate immune responses in BALB/C and C57BL/6J mouse strains infected with two 2009 pH1N1 isolates (ie, HH05 and HH15), a seasonal H1N1, and a human H5N1 influenza virus isolated from a fatal case. ${ }^{17}$ We show that C57BL/6J mice are more susceptible to $\mathrm{pH} 1 \mathrm{~N} 1$ influenza isolates, whereas $\mathrm{BALB} / \mathrm{c}$ mice are mostly resistant. No differences in susceptibility were observed for seasonal H1N1 influenza in both mouse models. In contrast, $\mathrm{H} 5 \mathrm{~N} 1$ virus infection was more virulent in BALB/C than C57BL/6J mice.

Both of the clinical pH1N1 isolates (ie, $\mathrm{HHO}$ and $\mathrm{HH} 15$ ) were obtained from patients who required hospitalization but recovered 5 to 6 days after admission to the hospital. However, it is difficult to assess the virulent potential of these isolates because both patients were treated with oseltamivir immediately after hospitalization. Both patients were healthy, without any underlying medical conditions. It is tempting to speculate about a potential more severe outcome in the absence of oseltamivir treatment or in patients with known risk factors for influenza. The viruses used in our experimental studies were isolated from patients before oseltamivir treatment.

The pathogenesis of $2009 \mathrm{pH} 1 \mathrm{~N} 1$ isolates has been studied in mice by several groups. However, most of these studies ${ }^{14,15,25}$ were performed in BALB/C mice; in these mice, the viruses replicated more efficiently compared with seasonal H1N1 influenza, but were generally not lethal. These data are consistent with our observations in BALB/c mice. Also, the $\mathrm{pH} 1 \mathrm{~N} 1$ isolate $\mathrm{MX} / 4482$, from a severe case, was not pathogenic in BALB/c mice (logMLD $_{50}>6$ PFU) but killed $50 \%$ of infected ferrets. ${ }^{15}$ On the other hand, WSLH049 (pH1N1), isolated from a patient who required hospitalization, had a $\log M L D_{50}$ of 4.5 PFU in BALB/c mice but was not studied in other mammalian models. ${ }^{14}$ The Neth/09 pH1N1 strain was previously shown to be lethal for C57BL/6 mice. ${ }^{26}$ Recently, some $2009 \mathrm{pH} 1 \mathrm{~N} 1$ strains presented heterogeneous virulence in a macaque model. ${ }^{27}$ Clearly, more studies using several pH1N1 isolates from mild and severe cases are needed in BALB/C and C57BL/6J mice and other mammalian models to identify an adequate model for the studies of $\mathrm{pH} 1 \mathrm{~N} 1$ pathogenesis and their correlation with clinical outcomes in humans.

Previously described markers predictive of virus adaptation to humans were not observed in 2009 pH1N1 viruses, suggesting that unrecognized novel determinants are responsible for their increased pathogenicity in several animal models. ${ }^{5}$ Growth kinetics in human lung cells revealed that $\mathrm{HH} 15$ grows to 10 times higher titers compared with $\mathrm{HH} 05$ (see Supplemental Figure S1 at $h$ ttp:// ajp.amjpathol.org). However, the overall growth of $\mathrm{pH} 1 \mathrm{~N} 1$ isolates was similar to seasonal H1N1 influenza, albeit high titers were detected during later time points with HH15. In contrast, human H5N1 influenza growth exhibited $\mathrm{pH} 1 \mathrm{~N} 1$ and seasonal $\mathrm{H} 1 \mathrm{~N} 1$ virus titers by more than four magnitudes. The $\mathrm{HH} 05$ and $\mathrm{HH} 15$ viruses differ by 12 amino acid exchanges in the genes encoding for PB2, PA, NP, HA, NA, and NS1 (see Supplemental Table S1 at http://ajp.amjpathol.org). The contribution of these substitutions to increased virulence in C57BL/6J mice is being investigated. Recently, the importin- $\alpha 7$ gene has been shown to be a key regulator of $2009 \mathrm{pH} 1 \mathrm{~N} 1$ but not H5N1 influenza pathogenicity in transgenic mouse models in mixed 129 $\times 1 /$ SvJ-C57BL/6 backgrounds. ${ }^{21}$ This further underlines that viral and host determinants responsible for H5N1 influenza pathogenicity are different from those determining 2009 pH1N1 influenza. Clearly, further studies are needed to identify viral and host determinants responsible for $2009 \mathrm{pH} 1 \mathrm{~N} 1$ and human H5N1 influenza pathogenicity in experimental animal models.

We observed that virus infection was predominantly restricted to the lungs of $\mathrm{HHO5}$ - and $\mathrm{HH} 15$-infected BALB/c mice, similar to seasonal H1N1 infection. In con- 

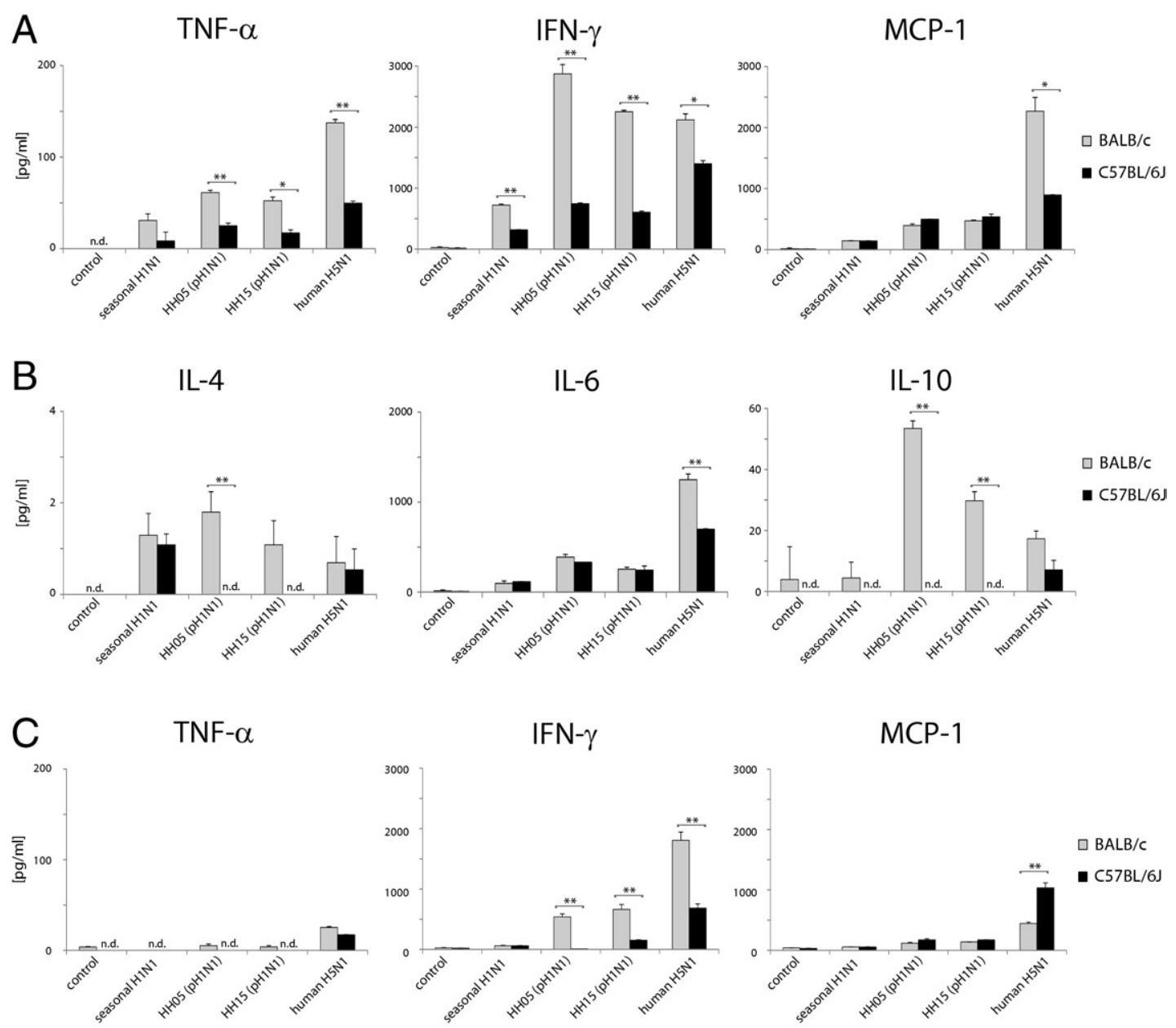

IFN- $\gamma$

MCP-1

D IL-4
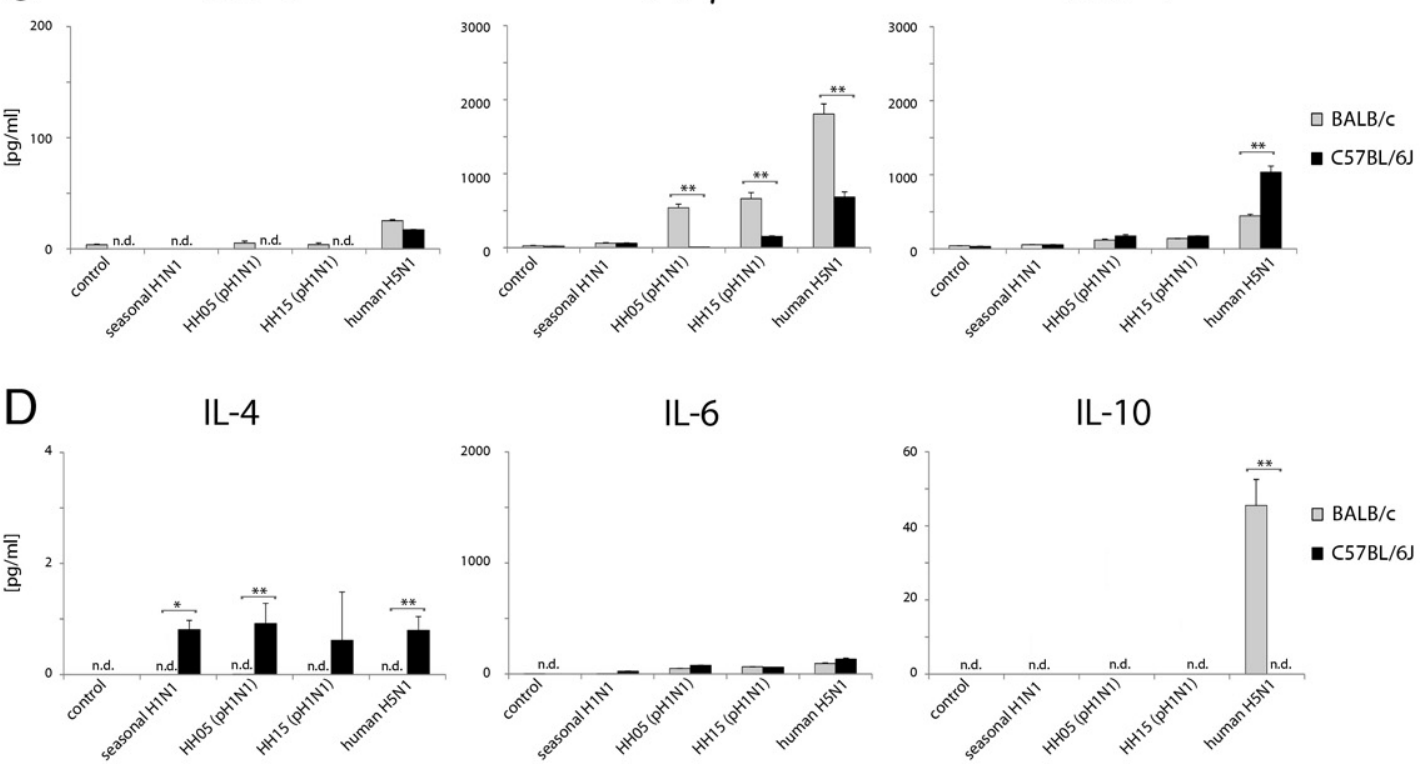

IL-6

IL-10
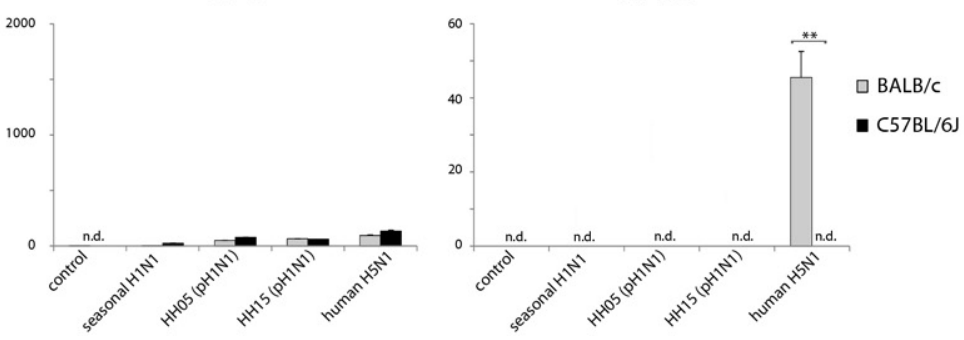

Figure 4. Cytokine response in BALB/c and C57BL/6J mice. BALB/c and C57BL/6J mice were infected with 105 PFU of seasonal H1N1, HH05, and HH15 (pH1N1) and with $10^{2}$ PFU of human H5N1. Control groups received PBS. Levels were measured for Th1 cytokines (TNF- $\alpha$, IFN- $\gamma$, and MCP-1) (A and $\mathbf{C}$ ) and Th2 cytokines (IL-4, IL-6, and IL-10) (B and D) in BALB/c (gray bars) and C57BL/6J (black bars) mice by enzyme-linked immunosorbent assay. Bars represent mean \pm SD cytokine concentrations of lung homogenates ( $\mathbf{A}$ and $\mathbf{B}$ ) from three animals or pooled serum samples $(\mathbf{C}$ and $\mathbf{D})$ from four to seven animals on day 6 p.i. n.d. indicates not detected (ie, cytokine levels less than the detection limit). The statistical significance of differences in cytokine levels between BALB/c and C57BL/6J mice was calculated by the Student's $t$-test $\left({ }^{*} P<0.05\right.$ and $\left.{ }^{* * *} P<0.01\right)$.

trast, significantly high virus titers were detected in the gut of HH15-infected C57BL/6J mice. However, no replicating virus could be detected in the gut tissues of $\mathrm{HH} 15$-infected C57BL/6J mice by IHC staining (see Supplemental Figure S2 at http://ajp.amjpathol.org). This suggests that extrapulmonary virus titers detected in $\mathrm{pH} 1 \mathrm{~N} 1$ infected C57BL/6J mice are likely representing different grades of viremia. Replicating virus in the gut was previously shown in cats fed with H5N1-infected chicks but not in animals infected via the respiratory tract. ${ }^{28}$ This further suggests that, upon respiratory tract infection, highly pathogenic strains can spread through the blood stream, as was previously shown for $\mathrm{H} 7 \mathrm{~N} 7$ and $\mathrm{H} 5 \mathrm{~N} 1$ isolates by several groups. ${ }^{18,28,29}$ The severity of lung damage observed correlated with lung titers detected in BALB/C mice. The lungs of $\mathrm{HH} 15-$ and $\mathrm{H} 5 \mathrm{~N} 1$-infected animals were more severely infiltrated and even partially hemorrhagic compared with $\mathrm{HH} 05$ in $\mathrm{BALB} / \mathrm{c}$ and $\mathrm{C} 57 \mathrm{BL} / 6 \mathrm{~J}$ mice. Interestingly, the finding that $\mathrm{HH} 15$ causes more lung damage than $\mathrm{HHO5}$ was observed in both mouse 
models. Furthermore, viral lung titers did not correlate with disease outcome in C57BL/6J mice, in contrast to BALB/c mice, because lung pathological features and virus tropism were similar in both mouse models. Thus, viral lung titers are not a reliable indicator of virus pathogenicity in C57BL/6J mice. Our findings strongly suggest that lethal outcome in C57BL/6J mice is not only affected by virus replication but also by other determinants (ie, host immune responses) significantly contribute to disease outcome.

Another important factor in pathogenesis is lymphopenia, which has been a hallmark for lethal influenza virus infection in our studies in the given host. HH15-infected animals underwent prolonged lymphocyte depletion in C57BL/6J mice, with a lethal outcome. pH1N1-caused lymphopenia was not previously reported because of the lack of an appropriate animal model to study $\mathrm{pH} 1 \mathrm{~N} 1$ pathogenesis. Accordingly, H5N1 infection also led to lymphopenia in C57BL/6J mice and more severely in $\mathrm{BALB} / \mathrm{c}$ mice. These observations indicate that virulent $\mathrm{pH} 1 \mathrm{~N} 1$ isolates and H5N1 viruses use immunosuppression, resulting from lymphocyte depletion as a mechanism to fuel the infection process, albeit in different host genetic backgrounds.

BALB/c mice are genetically primed to mount a Th2 response, whereas $\mathrm{C} 57 \mathrm{BL} / 6 \mathrm{~J}$ mice predominantly generate a Th1 response. ${ }^{23}$ Therefore, we compared levels of Th1 with levels of Th2 cytokines $^{23,24}$ in lung homogenates from BALB/C and C57BL/6J mice. Th1-primed cells play a predominant role in cellular immune responses, whereas Th2-primed cells are important for the generation of a humoral immune response. ${ }^{24}$ Th1 TNF- $\alpha$, MCP- 1 , and Th2 IL-6 also have proinflammatory functions. ${ }^{24}$ These cytokines play an important role in virus clearance but can be detrimental if they are excessively induced, as was previously described for $\mathrm{H} 5 \mathrm{N1} 1{ }^{30,31}$ After human H5N1 infection, Th1/Th2 hypercytokinemia and severe lymphopenia were observed in BALB/c mice and, to a lesser extent, in C57BL/6 mice. Similar observations were previously described for H5N1 and H7N7 influenza viruses in mice. ${ }^{18,32} \mathrm{H} 5 \mathrm{~N} 1$-induced hypercytokinemia and high virus load have been associated with lethal outcome in humans. ${ }^{31}$ However, the absence of single cytokines [ie, chemokine ligand 2 (MCP-1), IL-6, and TNF- $\alpha$ ] in single-knockout mice was not protective, but the double knockout of TNF receptor 1/2 reduced lethality in H5N1infected mice, ${ }^{33}$ suggesting that additional determinants contribute to $\mathrm{H} 5 \mathrm{~N} 1$ pathogenesis.

Remarkably, we observed that increased $\mathrm{pH} 1 \mathrm{~N} 1$ pathogenicity in C57BL/6J mice correlated with reduced Th1 and Th2 cytokines compared with BALB/c mice. In general, no significant differences in cytokine levels were observed between $\mathrm{HH} 05-$ and $\mathrm{HH} 15$-infected C57BL/6J mice. In pH1N1-infected BALB/c mice, only systemic IFN- $\gamma$ levels were increased, consistent with the local lung response. Interestingly, IL-10 and IFN- $\gamma$ levels were increased in the lungs of $\mathrm{HHO5}$ - and $\mathrm{HH} 15$-infected BALB/c mice and systemically in H5N1-infected BALB/C mice. However, controversial findings were reported on the role of IL-10 in influenza virus infection. Blocking the $\mathrm{IL}-10$ response has increased morbidity and lung inflam- mation $^{34}$; on the other hand, it may reduce mortality in influenza virus-infected mice. ${ }^{35}$ The exact role of IL-10 in pH1N1 and H5N1 influenza virus infection needs further investigation to determine whether the host genetic background influences the beneficial or detrimental role of cytokine responses.

\section{Acknowledgments}

We thank Susanne Huggett (Medilys, Asklepios Clinics, Hamburg, Germany) and Stefan Schmiedel (University Hospital Eppendorf, Hamburg, Germany) for providing clinical information on patients infected with 2009 H1N1 influenza and Hans-Dieter Klenk (Institute of Virology, Philipps University of Marburg, Marburg, Germany) and Michael Bruns (Heinrich-Pette-Institute, Hamburg, Germany) for critical reading of the manuscript.

\section{References}

1. Fouchier RA, Schneeberger PM, Rozendaal FW, Broekman JM, Kemink SA, Munster V, Kuiken T, Rimmelzwaan GF, Schutten M, Van Doornum GJ, Koch G, Bosman A, Koopmans M, Osterhaus AD: Avian influenza A virus (H7N7) associated with human conjunctivitis and a fatal case of acute respiratory distress syndrome. Proc Natl Acad Sci U S A 2004, 101:1356-1361

2. Subbarao K, Klimov A, Katz J, Regnery H, Lim W, Hall H, Perdue M, Swayne D, Bender C, Huang J, Hemphill M, Rowe T, Shaw M, Xu X, Fukuda K, Cox N: Characterization of an avian influenza A (H5N1) virus isolated from a child with a fatal respiratory illness. Science 1998, 279:393-396

3. Klenk HD, Matrosovich M, Stech J: Avian Influenza. Monogr. Virol. Basel, Karger, 2008, p 27

4. Fraser C, Donnelly CA, Cauchemez S, Hanage WP, Van Kerkhove MD, Hollingsworth TD, Griffin J, Baggaley RF, Jenkins HE, Lyons EJ, Jombart T, Hinsley WR, Grassly NC, Balloux F, Ghani AC, Ferguson NM, Rambaut A, Pybus OG, Lopez-Gatell H, Alpuche-Aranda CM, Chapela IB, Zavala EP, Guevara DM, Checchi F, Garcia E, Hugonnet S, Roth C: Pandemic potential of a strain of influenza $A(\mathrm{H} 1 \mathrm{~N} 1)$ : early findings. Science 2009, 324:1557-1561

5. Garten RJ, Davis CT, Russell CA, Shu B, Lindstrom S, Balish A, et al: Antigenic and genetic characteristics of swine-origin 2009 A(H1N1) influenza viruses circulating in humans. Science 2009, 325:197-201

6. Dawood FS, Jain S, Finelli L, Shaw MW, Lindstrom S, Garten RJ, Gubareva LV, Xu X, Bridges CB, Uyeki TM: Emergence of a novel swine-origin influenza A (H1N1) virus in humans. N Engl J Med 2009, 360:2605-2615

7. Riquelme A, Alvarez-Lobos M, Pavez C, Hasbun P, Dabanch J, Cofre C, Jimenez J, Calvo M: Gastrointestinal manifestations among Chilean patients infected with novel influenza A (H1N1) 2009 virus. Gut 2009, 58:1567-1568

8. Writing Committee of the WHO Consultation on Clinical Aspects of Pandemic (H1N1) Influenza, Bautista E, Chotpitayasunondh T, Gao Z, Harper SA, Shaw M, Uyeki TM, Zaki SR, Hayden FG, Hui DS, Kettner JD, Kumar A, Lim M, Shindo N, Penn C, Nicholson KG: Clinical aspects of pandemic 2009 influenza $A(H 1 N 1)$ virus infection. N Engl J Med 2010, 362:1708-1719

9. Dominguez-Cherit G, Lapinsky SE, Macias AE, Pinto R, EspinosaPerez L, de la Torre A, Poblano-Morales M, Baltazar-Torres JA, Bautista E, Martinez A, Martinez MA, Rivero E, Valdez R, Ruiz-Palacios G, Hernandez M, Stewart TE, Fowler RA: Critically ill patients with 2009 influenza A (H1N1) in Mexico. JAMA 2009, 302:1880-1887

10. Jain S, Kamimoto L, Bramley AM, Schmitz AM, Benoit SR, Louie J Sugerman DE, Druckenmiller JK, Ritger KA, Chugh R, Jasuja S, Deutscher M, Chen S, Walker JD, Duchin JS, Lett S, Soliva S, Wells EV, Swerdlow D, Uyeki TM, Fiore AE, Olsen SJ, Fry AM, Bridges CB, Finelli L; 2009 Pandemic Influenza A (H1N1) Virus Hospitalizations Investigation Team: Hospitalized patients with $2009 \mathrm{H} 1 \mathrm{~N} 1$ influenza in 
the United States, April-June 2009. N Engl J Med 2009, 361:1935-1944

11. Kumar A, Zarychanski R, Pinto R, Cook DJ, Marshall J, Lacroix J, Stelfox T, Bagshaw S, Choong K, Lamontagne F, Turgeon AF, Lapinsky S, Ahern SP, Smith O, Siddiqui F, Jouvet P, Khwaja K, McIntyre L, Menon K, Hutchison J, Hornstein D, Joffe A, Lauzier F, Singh J, Karachi T, Wiebe K, Olafson K, Ramsey C, Sharma S, Dodek P, Meade M, Hall R, Fowler RA: Critically ill patients with 2009 influenza A (H1N1) infection in Canada. JAMA 2009, 302:1872-1879

12. Louie JK, Acosta M, Winter K, Jean C, Gavali S, Schechter R, Vugia D, Harriman K, Matyas B, Glaser CA, Samuel MC, Rosenberg J, Talarico J, Hatch D: Factors associated with death or hospitalization due to pandemic 2009 influenza A (H1N1) infection in California. JAMA 2009, 302:1896-1902

13. Webb SA, Pettila V, Seppelt I, Bellomo R, Bailey M, Cooper DJ, Cretikos M, Davies AR, Finfer S, Harrigan PW, Hart GK, Howe B, Iredell JR, McArthur C, Mitchell I, Morrison S, Nichol AD, Paterson DL, Peake S, Richards B, Stephens D, Turner A, Yung M: Critical care services and 2009 H1N1 influenza in Australia and New Zealand. N Engl J Med 2009, 361:1925-1934

14. Itoh Y, Shinya K, Kiso M, Watanabe T, Sakoda Y, Hatta M, et al: In vitro and in vivo characterization of new swine-origin H1N1 influenza viruses. Nature 2009, 460:1021-1025

15. Maines TR, Jayaraman A, Belser JA, Wadford DA, Pappas C, Zeng H, Gustin KM, Pearce MB, Viswanathan K, Shriver ZH, Raman R, Cox NJ, Sasisekharan R, Katz JM, Tumpey TM: Transmission and pathogenesis of swine-origin $2009 \mathrm{~A}$ (H1N1) influenza viruses in ferrets and mice. Science 2009, 325:484-487

16. Munster VJ, de Wit E, van den Brand JM, Herfst S, Schrauwen EJ, Bestebroer TM, van de Vijver D, Boucher CA, Koopmans M, Rimmelzwaan GF, Kuiken T, Osterhaus AD, Fouchier RA: Pathogenesis and transmission of swine-origin 2009 A (H1N1) influenza virus in ferrets. Science 2009, 325:481-483

17. Puthavathana P, Auewarakul P, Charoenying PC, Sangsiriwut K, Pooruk P, Boonnak K, Khanyok R, Thawachsupa P, Kijphati R, Sawanpanyalert P: Molecular characterization of the complete genome of human influenza H5N1 virus isolates from Thailand. J Gen Virol 2005, 86:423-433

18. Gabriel G, Klingel K, Planz O, Bier K, Herwig A, Sauter M, Klenk HD: Spread of infection and lymphocyte depletion in mice depends on polymerase of influenza virus. Am J Pathol 2009, 175:1178-1186

19. Reed LH, Muench $\mathrm{H}$ : A simple method of estimating fifty percent endpoints. Am J Hygiene 1938, 27:493-497

20. Gabriel G, Herwig A, Klenk HD: Interaction of polymerase subunit PB2 and NP with importin alpha1 is a determinant of host range of influenza A virus. PLoS Pathog 2008, 4:e11

21. Gabriel G, Klingel K, Otte A, Thiele S, Hudjetz B, Arman-Kalcek G, Sauter M, Shmidt T, Rother F, Baumgarte S, Keiner B, Hartmann E, Bader M, Brownlee GG, Fodor E, Klenk HD: Differential use of importin- $\alpha$ isoforms governs cell tropism and host adaptation of influenza virus. Nat Commun 2011, 2:156

22. Stech J, Stech O, Herwig A, Altmeppen H, Hundt J, Gohrbandt S, Kreibich A, Weber S, Klenk HD, Mettenleiter TC: Rapid and reliable universal cloning of influenza A virus genes by target-primed plasmid amplification. Nucleic Acids Res 2008, 36:e139
23. Heinzel FP, Sadick MD, Holaday BJ, Coffman RL, Locksley RM: Reciprocal expression of interferon gamma or interleukin 4 during the resolution or progression of murine leishmaniasis: evidence for expansion of distinct helper T cell subsets. J Exp Med 1989, 169:59-72

24. Kidd P: Th1/Th2 balance: the hypothesis, its limitations, and implications for health and disease. Altern Med Rev 2003, 8:223-246

25. Belser JA, Wadford DA, Pappas C, Gustin KM, Maines TR, Pearce MB, Zeng H, Swayne DE, Pantin-Jackwood M, Katz JM, Tumpey TM: Pathogenesis of pandemic influenza $A(\mathrm{H} 1 \mathrm{~N} 1)$ and triple-reassortant swine influenza A (H1) viruses in mice. J Virol 2010, 84:4194-4203

26. Manicassamy B, Medina RA, Hai R, Tsibane T, Stertz S, Nistal-Villán E, Palese P, Basler CF, García-Sastre A: Protection of mice against lethal challenge with 2009 H1N1 influenza A virus by 1918-like and classical swine H1N1 based vaccines. PLoS Pathog 2010, 6:e1000745

27. Safronetz D, Rockx B, Feldmann F, Belisle SE, Palermo RE, Brining D, Gardner D, Proll SC, Marzi A, Tsuda Y, Lacasse RA, Kercher L, York A, Korth MJ, Long D, Rosenke R, Shupert WL, Aranda CA, Mattoon JS, Kobasa D, Kobinger G, Li Y, Taubenberger JK, Richt JA, Parnell M, Ebihara H, Kawaoka Y, Katze MG, Feldmann H: Pandemic swineorigin $\mathrm{H} 1 \mathrm{~N} 1$ influenza $\mathrm{A}$ virus isolates show heterogeneous virulence in macaques. J Virol 2011, 85:1214-1223

28. Rimmelzwaan GF, van Riel D, Baars M, Bestebroer TM, van Amerongen G, Fouchier RA, Osterhaus AD, Kuiken T: Influenza A virus (H5N1) infection in cats causes systemic disease with potential nove routes of virus spread within and between hosts. Am J Pathol 2006, 168:176-183; quiz, 364

29. Gao P, Watanabe S, Ito T, Goto H, Wells K, McGregor M, Cooley AJ, Kawaoka Y: Biological heterogeneity, including systemic replication in mice, of $\mathrm{H} 5 \mathrm{~N} 1$ influenza $A$ virus isolates from humans in Hong Kong. J Virol 1999, 73:3184-3189

30. Cheung CY, Poon LL, Lau AS, Luk W, Lau YL, Shortridge KF, Gordon $S$, Guan Y, Peiris JS: Induction of proinflammatory cytokines in human macrophages by influenza $A$ (H5N1) viruses: a mechanism for the unusual severity of human disease? Lancet 2002, 360:1831-1837

31. de Jong MD, Simmons CP, Thanh TT, Hien VM, Smith GJ, Chau TN, Hoang DM, Chau NV, Khanh TH, Dong VC, Qui PT, Cam BV, Ha do Q, Guan Y, Peiris JS, Chinh NT, Hien TT, Farrar J: Fatal outcome of human influenza A ( $\mathrm{H} 5 \mathrm{~N} 1)$ is associated with high viral load and hypercytokinemia. Nat Med 2006, 12:1203-1207

32. Szretter KJ, Gangappa S, Lu X, Smith C, Shieh WJ, Zaki SR, Sambhara S, Tumpey TM, Katz JM: Role of host cytokine responses in the pathogenesis of avian H5N1 influenza viruses in mice. J Virol 2007, 81:2736-2744

33. Salomon R, Hoffmann E, Webster RG: Inhibition of the cytokine response does not protect against lethal H5N1 influenza infection. Proc Natl Acad Sci U S A 2007, 104:12479-12481

34. Sun J, Madan R, Karp CL, Braciale TJ: Effector T cells control lung inflammation during acute influenza virus infection by producing IL10. Nat Med 2009, 15:277-284

35. McKinstry KK, Strutt TM, Buck A, Curtis JD, Dibble JP, Huston G, Tighe M, Hamada H, Sell S, Dutton RW, Swain SL: IL-10 deficiency unleashes an influenza-specific Th17 response and enhances survival against high-dose challenge. J Immunol 2009, 182:73537363 